\title{
Livestock production development in AP Vojvodina
}

\author{
SNEŽANA TRIVUNOVIĆ - LJUBA ŠTRBAC - DOBRILA JANKOVIĆ - \\ DRAŠKO IVANOVIĆ - IVAN RADOVIĆ - MILE MIRKOV - \\ IVAN PIHLER - SINIŠA BJEDOV - MOMČILO ŠARAN \\ University of Novi Sad, Faculty of Agriculture, Novi Sad, Serbia \\ snezana.trivunovic@stocarstvo.edu.rs
}

\begin{abstract}
Summary
The aim of this paper is to present the effects of breeding program implementation on the development of animal breeding in Vojvodina since 2010. Data from the Main breeding organization (controlled population) and data from the Statistical Office of the Republic of Serbia (total population) were used as a basis for this research. The main breeding organization is the Departmant of Animal Science, Faculty of Agriculture, University of Novi Sad that implemented the main breeding programs in cattle, pig, sheep, goat, horse and poultry production. The milk yield in a recorded population of Holstein Friesian and Simmental cows shows evident phenotypic increasing trend as opposed to a population that is not controlled. The results of the selection measures in Vojvodina show that pig breeding has an upward trend and that we have an increasing number of small and medium (family) farms. Interest in sheep and goat production is increasing primarily because of the high demand for products made from sheep meat and goat milk and meat. In the recent decades, Vojvodina has been faced with a decrease in the number of horses. At the same time, there is an increasing interest in sports horses and recreation. According to poultry production results of parental flocks, an increasing tendency was observed in the production of controlled flocks recently, while the number of breeding stock breeders was reduced.
\end{abstract}

Keywords: livestock production, breeding programs, population size

\section{Introduction}

In the Republic of Serbia livestock breeding is the leading branch of agriculture. $77.5 \%$ of the total number of agricultural holdings are engaged in livestock production (Popović, 2014). According to his research, almost eight out of ten farms have at least one livestock line in the production structure, while farms with livestock production lines use $70 \%$ of agricultural land and the dominant share of other resources, such as labor and mechanization. The author also points to the regionalization of livestock production in the Republic of Serbia. Pig farming is mostly concentrated in Vojvodina, with $41 \%$ of the animals. Cattle production is mostly located in the central part of Serbia, while in the territory of 
Vojvodina, $27.8 \%$ of the cattle are bred. The number of sheep bred in the Vojvodina is $20 \%$, the goat $31 \%$, and the poultry $45 \%$ of the total number of animals. Novković et al. (2011) in the research related to livestock production in Vojvodina from 2001 to 2009 included the economically significant types of livestock (cattle, pigs, sheep and poultry) with the aim of quantitative analysis of production changes and comparisons of them with Hungary. The authors calculated a tendency of slight decrease of basic herd of pigs $(-0.69 \%)$, stagnation of cows and heifers as well as poultry $(0.12 \%$ and $-0.11 \%)$, while in sheep farming they calculated a high growth rate due to import of breeding animals (7.87\%). Compared to Hungary, the authors point to an unfavorable situation that is reflected in a lower concentration of almost all species of livestock. The biggest differences are in cattle and sheep breeding, and the smallest in pig breeding, while the concentration of poultry is even slightly better than in Hungary. Aleksić et al. (2009) assessed the state of livestock in Serbia as not viable, pointing out that the number of animals of all species is constantly decreasing, which is especially noticeable for female animals used in reproduction (pregnant cows and heifers, pregnant sows and gilts, breeding sheep and goats).

To make livestock production economically viable, it is necessary to have clearly defined breeding goals to be achieved, as well as programs for their realization (Bogdanović et al., 2005). Selection of livestock in Vojvodina institutionally started with the establishment of the Provincial Livestock Institute in 1950. Over the years, the organizational structure has been changed several times, and finally by entering into force of the Livestock Act (Official Gazette of RS 41/09), Department of Animal Husbandry, Faculty of Agriculture in Novi Sad, in 2010, received "Decision on enrollment in the Register of Breeding Organizations of the Ministry of Agriculture, Forestry and Water Management" as the Main breeding organization for the Autonomous Province of Vojvodina (AP Vojvodina) and the same year started the implementation of the Main breeding programs.

The aim of this paper is to present the effects of breeding programs implementation on the development of animal breeding in Vojvodina since 2010.

\section{Material and methods}

As a material for this research data from Main breeding organization (controlled population) and data from Statistical Office of the Republic of Serbia (total population) were used. Main breeding organization collects, process and analyzes data related to population size and productivity in controlled population of animals. Data were collected from primary and 
regional breeding organizations, through quarterly reporting documentation and annual selection review which is obligatory event defined in the main breeding programs.

\section{Results and discussion}

\section{Cattle production}

The dominant breed in controlled cattle population in Vojvodina is Holstein-Friesian (HF). According to the Main breeding organization, the Holstein-Friesian (HF) breed in 2005. constituted $98 \%$ of the controlled cattle population in Vojvodina (Main breeding organization, 2011), but over the last ten years, the breed structure has changed and there is an increasing interest in dualpurpose (Simmental and Brown Swiss) and fattening breeds of cattle (Hereford, Angus, Limousine and Sharoles). In 2017 the breed structure of the controlled cattle population in Vojvodina constituted $76 \%$ HF breed, $21 \%$ Simmental and $3.16 \%$ other breeds.

The size of the total and controlled population of Holstein-Friesian and Simmental cows and heifers since 2010 is increasing, as well as the proportion of the controlled in relation to the total population of cows and heifers in Vojvodina (Figure 1). The aim of increasing the controlled population was achieved for both breeds, given that the population of Holstein-Friesian cows in 2017 increased by $81.90 \%$ compared to 2010, and Simmental by $204.27 \%$. The proportion of the controlled in the total population of cattle in Vojvodina in 2017 increased by $26.32 \%$ compared to 2010 and reflects the interest of farmers for the implementation of breeding programs on their farms. It is also the result of increased incentives for genetic improvement of livestock by the Ministry of Agriculture, Forestry and Water Management of the Republic of Serbia. In some other countries of Central and Eastern Europe share ranges from $77.8 \%$ in Austria to $93.9 \%$ in Czech Republic, while in the Poland is 30.5\% (Bucek et al., 2014). Considering the total and controlled cows and heifers population size, there is room for further increase of the ratio of controlled in relation to the total cattle population.

The average milk yields in a recorded (HF, Simmental) and total population (Figure 2), shows an increasing phenotypic trend of this very important production trait in recorded population, as well as higher absolute values, in contrast to total population, indicating the impact of implementation of breeding programs. However, although the average milk yield of HF population increased by $10 \%$, the goal of $7500 \mathrm{~kg}$ of milk in 305-d lactation has not been achieved. The yield of more than $5000 \mathrm{~kg}$ of milk for the Simmental breed has been achieved in the last year of breeding program implementation. 
Figure 1. Size of the total and recorded cows and heifers population and share of recorded relative to the total population in the period 2010-2017

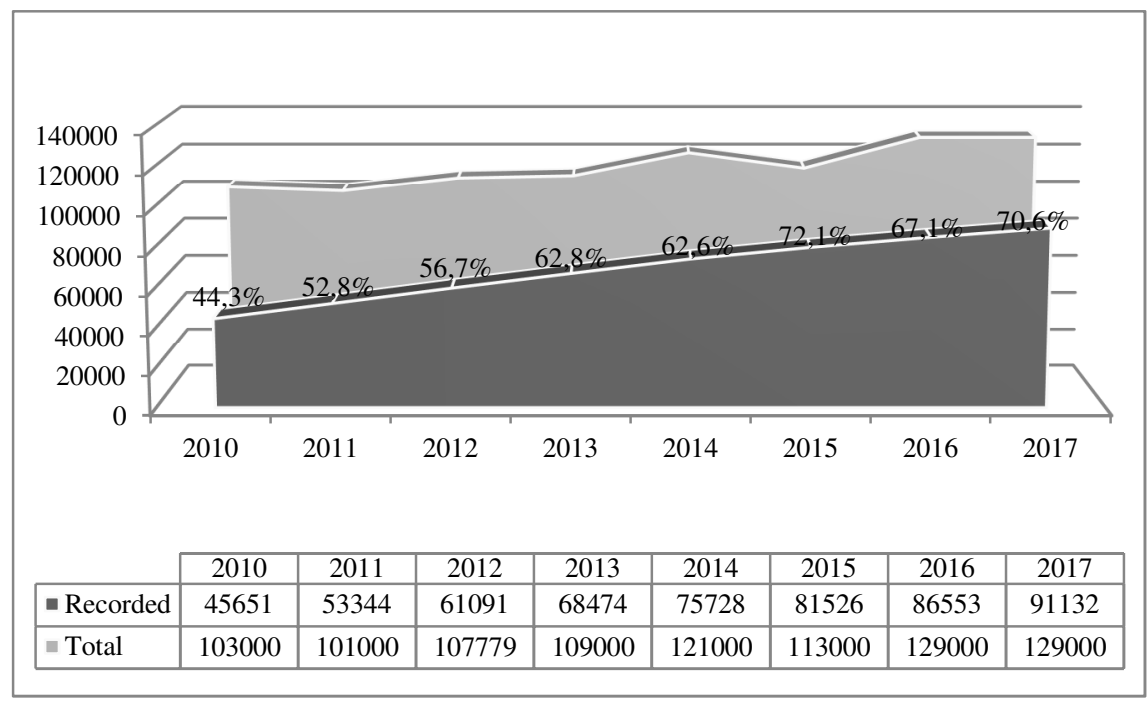

Figure 2. Phenotypic trends for 305-d milk yield of Holstein Friesian, Simmental and total population in the period 2010-2017

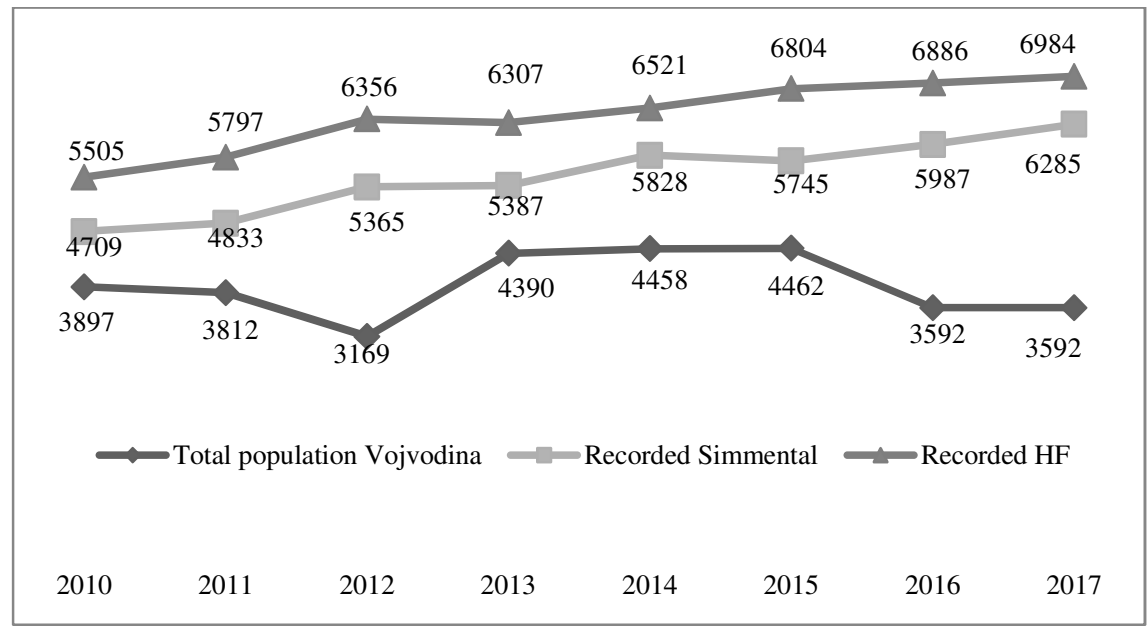

Increase of milk yield in the period 2010-2017 is $1479 \mathrm{~kg}$ for the HF and $1580 \mathrm{~kg}$ for the Simmental cows. Milk fat yield and content also shows increasing phenotypic trend in both breeds; milk fat yield was increased by $50 \mathrm{~kg}$ in the HF (fat content, 3.78\% vs. 3.36\%) and by $55 \mathrm{~kg}$ 
in the Simmental (fat content $3.92 \%$ vs. 3.52\%) (Main breeding organization, 2018).

Given the genetic potential of the HF cows for milk production, determined average milk yield in the HF population in Vojvodina is not satisfactory. The average milk yield and milk fat content of HF cows are lower in relation to Croatia $(7889,4.0 \%)($ CAA, 2018), as well as in relation to Slovenia $(8042,3.97 \%)$ (Kmetijski Institut Slovenije, 2018). But, we need to know that the HF population in Vojvodina is very heterogeneous in many parameters (herd management, selection activities, herd size, etc.). In the former large state farms, for example, the average milk yield of HF cows are $8500 \mathrm{~kg}$. The average milk yield of Simmental cows in Vojvodina is higher in relation to Croatia (5030 kg, $4.01 \%)$, as well as in relation to Slovenia $(5873 \mathrm{~kg}, 4.10 \%)$.

Dairy production is a significant branch of agriculture and the overall economy in Vojvodina. As well as previously analyzes (Trivunović et al., 2015), this article shows significant positive effects of implementation of breeding programs for HF and Simmental cattle on the overall performance of dairy cattle. In the region of ex-Yugoslavia, the share of the recorded relative to the total population is increasing, as well as the average milk yield, while the total population size is decreasing, (Stoković et al., 2007).

Beginning of the beef cattle recording system and the establishment of a database for the selection and further improvement of beef cattle is related to the Department of Animal Husbandry, Faculty of Agriculture in Novi Sad, for the second half of 2013. In 2013, a total of 1223 heads of beef cattle were raised in Vojvodina: Hereford-1038, Limousine-45, Sharole-44, Angus-96. In 2017, the number of recorded beef cattle was 2063: Hereford 1064, Sharole-266, Limousin-109, Angus-587.

Pig production

Controlling the productivity of sows is a measure aimed at tracking production results (conception, farrowing rate, fertility, maternal effect, and others production traits) in order to perform an appropriate selection of parents to produce the next generation. The number of sows under productivity control is still on the rise and has a positive trend line (Table 1).

The control of the productivity of the boars are a selection measure that follows the production indicators of boars (bore efficiency, litter size, piglets with anomalies, quality of sperm and others production traits), where the aim is to choose boar which according to their production characteristics correspond to the aim of production. Also, due to the purchase of seeds from artificial insemination centers, in order to avoid breeding animals who have common ancestors and to improve 
productivity by using the highest quality boars, the number of boars under control additionally oscillates.

Table 1. Number of animals under productivity control

\begin{tabular}{lcccc}
\hline Year & $\begin{array}{c}\text { Control of } \\
\text { sow } \\
\text { productivity }\end{array}$ & $\begin{array}{c}\text { Control of } \\
\text { productivity } \\
\text { boars }\end{array}$ & $\begin{array}{c}\text { Number of sows in } \\
\text { Vojvodina } \\
\text { (Statistical Office of the } \\
\text { Republic of Serbia) }\end{array}$ & $\begin{array}{c}\text { Sows under } \\
\text { control in } \\
\text { population (\%) }\end{array}$ \\
\hline 2010 & 37,915 & 843 & 139,000 & 27.28 \\
2011 & 38,476 & 827 & 121,000 & 31.80 \\
2012 & 27,547 & 388 & - & - \\
2013 & 34,001 & 461 & 103,000 & 33.01 \\
2014 & 28,714 & 584 & 115,000 & 24.97 \\
2015 & 32,809 & 552 & 119,000 & 27.57 \\
2016 & 40,686 & 504 & 110,000 & 36.99 \\
2017 & 38,193 & 578 & 108,000 & 35.36 \\
\hline
\end{tabular}

The traits that measured by performance test and traits that are included in the calculation of the selection index are: backfat thickness and side fat thickness, depth of musculus longissimus (MLD) and life gain. The results of the performance testing of boars are shown in Table 2. We can see that the number of tested boars are decreasing, which is also recorded by Trivunović et al. (2014). One of the consequences of the decreasing the number of tested animal is increased import of animals, and the use of semen from artificial insemination centers. The results obtained by the performance test are shown in Table 2. Based on the data of the test results (weight gain, feed conversion, back fat thickness, \% of meat in carcasses, number of tits, constitution, size and number of litter from which originates), the best boars should be selected (Yoo and Lee, 2011).

The data are encouraging, since the effect of the continuous implementation of the Main Breeding Program, and the last 10 years state stimulation of farmers in the production of quality breeding material, gives positive results. It should also be said that the life gain and MLD are also increasing, while the backfat thickness and side fat thickness are in decline. Radović et al. (2015) also recorded a positive results (increasing) life gain and MLD in performance test gilts. Selection pressure should be increased to economically important traits. Also, it is necessary to test breeding methods and improve them. In order to achieve the appropriate selection success, continuity is needed, which can be achieved by stable market and production without major oscillations. 
Table 2. Results of the performance teste of boar

\begin{tabular}{lccccccc}
\hline Year & $\begin{array}{c}\text { Number of } \\
\text { tested } \\
\text { boars }\end{array}$ & $\begin{array}{c}\text { Age at the } \\
\text { end of test, } \\
\text { days }\end{array}$ & $\begin{array}{c}\text { Body } \\
\text { weight }\end{array}$ & $\begin{array}{c}\text { Life gain, } \\
\left(\mathrm{kg} \mathrm{days}^{-1}\right)\end{array}$ & $\begin{array}{c}\text { Backfat } \\
\text { thicknes } \\
\text { s }(\mathrm{mm})\end{array}$ & $\begin{array}{c}\text { Side fat } \\
\text { thickness } \\
(\mathrm{mm})\end{array}$ & $\begin{array}{c}\text { MLD } \\
(\mathrm{mm})\end{array}$ \\
\hline 2010 & 1294 & 196 & 111 & 0.556 & 11.1 & 8.1 & 68.2 \\
2011 & 872 & 199 & 112 & 0.552 & 13.0 & 12.8 & 69.8 \\
2012 & 883 & 187 & 114 & 0.609 & 17.2 & 16.9 & 74.3 \\
2013 & 812 & 170 & 113 & 0.665 & 17.6 & 18.1 & 77.1 \\
2014 & 987 & 191 & 112 & 0.585 & 15.92 & 16.38 & 76.69 \\
2015 & 827 & 188 & 107 & 0.569 & 13.9 & 13.7 & 72.6 \\
2016 & 724 & 186 & 112 & 0.603 & 12.81 & 13.02 & 74.82 \\
2017 & 594 & 180 & 110 & 0.615 & 11.03 & 11.44 & 75.14 \\
\hline
\end{tabular}

\section{Sheep production}

Intensive sheep production is based on genetic potential and life cycle of animal. It is mainly oriented towards increase of biologic bases for sheep reproduction. Most intensive mating activity is during October and November and then fertility rate is highest (highest number of successful pregnancies is achieved with the highest number of lambs per sheep) (Mekić et al., 2011, 2017).

Of the estimated 275,000 sheep in APV in 2017. (Statistical Office of the Republic of Serbia), only $29.44 \%$ were under the breeding programme (Figure 3).

Figure 3. Total numbers of sheep in APV and numbers of sheep under breeding controlled

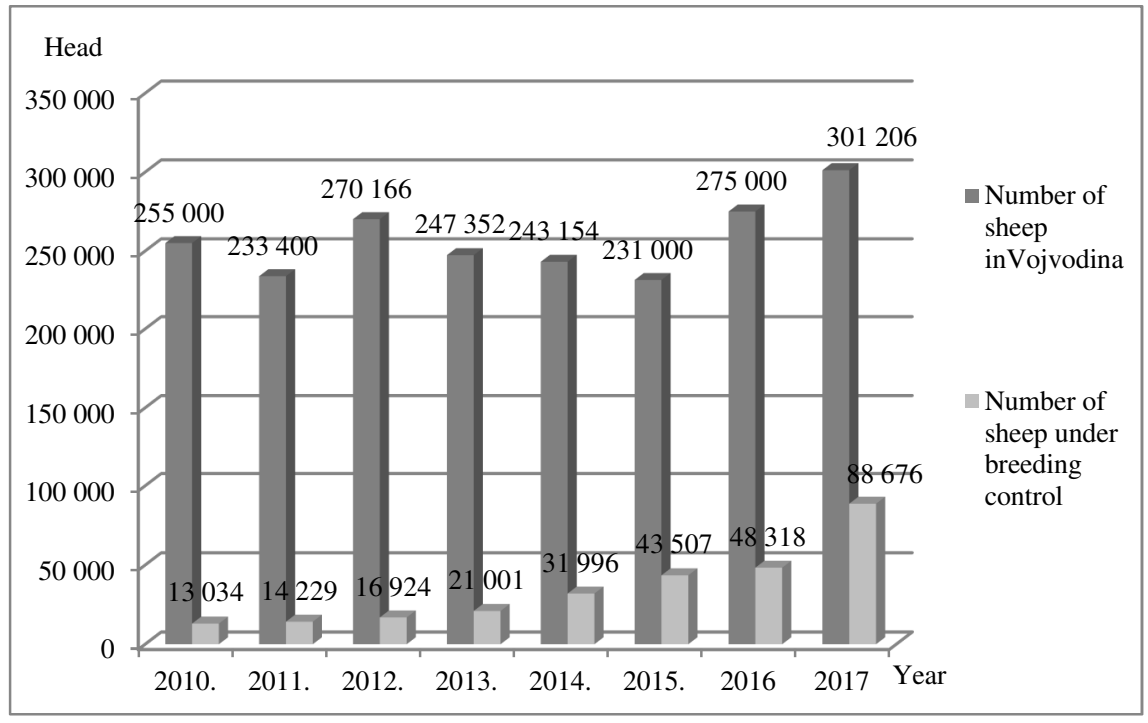


Sheep breeding is controlled through the monitoring of fertility, birth weight of lambs, body weight of ewes and wool production (Table 3). In APV most popular breeds were: Merino ladschaf and ile de france, which together make up more than $88 \%$ of controlled population of sheep. The average herd size under the breeding programme in 2017 was 55.7 heads, while most breeders had 30-120 heads.

Table 3. Findings from sheep monitoring under the APV breeding programme, 2017

\begin{tabular}{lccccc}
\hline \multicolumn{1}{c}{ Breed } & Fertility & $\begin{array}{c}\text { Birth } \\
\text { weight } \\
(\mathrm{kg})\end{array}$ & $\begin{array}{c}\text { Weaning } \\
\text { weight } \\
(\mathrm{kg})\end{array}$ & $\begin{array}{c}\text { Woll } \\
\text { production } \\
(\mathrm{kg})\end{array}$ & $\begin{array}{c}\text { Body } \\
\text { weight of } \\
\text { ewes } \\
(\mathrm{kg})\end{array}$ \\
\hline Bergamo & 1.34 & 4.12 & 30.98 & 3.41 & 71.41 \\
Tsigai & 1.32 & 4.12 & 30.08 & 3.43 & 74.51 \\
Choka tsigai & 1.20 & 3.59 & 28.07 & 3.41 & 66.60 \\
Ile de France & 1.47 & 4.07 & 30.66 & 3.55 & 68.63 \\
Man meet merino & 1.18 & 5.39 & 34.55 & 4.43 & 82.59 \\
Suffolk & 1.53 & 4.28 & 31.36 & 3.04 & 69.06 \\
Charollais & 1.33 & 4.19 & 31.66 & 3.41 & 71.47 \\
Texel & 1.66 & 4.11 & 31.24 & 3.29 & 72.77 \\
Merino ladschaf & 1.31 & 4.19 & 31.02 & 3.57 & 70.95 \\
British milk sheep & 1.76 & 3.46 & 29.11 & 2.78 & 63.42 \\
Romanov sheep & 2.40 & 2.26 & 19.00 & 1.87 & 55.74 \\
\hline
\end{tabular}

\section{Goat production}

In Serbia goat breeding started to develop with imports of Saanen and Alpine goats for crossing with Balkan goats to improve milk production (Pihler, 2014). As in other European countries, in Vojvodina, goats are bred mainly for milk production, and milk yield per head is the most important production traits. Of the estimated 46,393 goats in Vojvodina in 2017. (Statistical Office of the Republic of Serbia), only 16.09\% were under the breeding programme (Figure 4).

In Vojvodina, three breeds are under controlled breeding - Alpine, Saanen, and Balkan - of which Alpine goats are the most numerous. The average herd size under the breeding programme in 2017 was 44.17 heads, while most breeders had $30-120$ heads. Goat breeding is controlled through the monitoring of fertility, birth weight of kids, body weight of goats and milk yield of Alpine and Saanen goats (Table 4). 
Figure 4. Total numbers of goats in APV and numbers of goats under breeding controlled

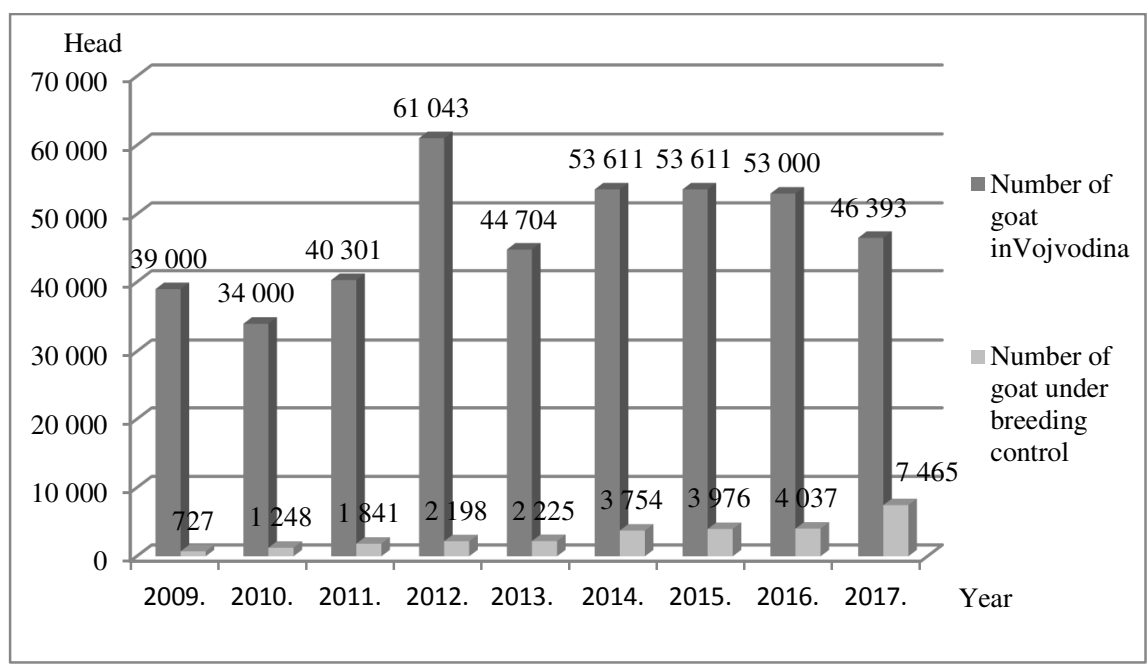

Table 4. Findings from goat monitoring under the APV breeding programme, 2017

\begin{tabular}{|c|c|c|}
\hline Parameter & Alpine & Saanen \\
\hline Days of lactation & 217.34 & 241.20 \\
\hline Fertility $(\%)$ & 1.62 & 1.54 \\
\hline Milk (kg) & 592.31 & 754.56 \\
\hline$\%$ fat content & 3.51 & 3.22 \\
\hline$\%$ protein content & 3.12 & 3.20 \\
\hline Birth weight (kg) & 3.19 & 2.81 \\
\hline Body weight of goats $(\mathrm{kg})$ & 54.80 & 61.52 \\
\hline
\end{tabular}

\section{Horse production}

In the last decades Vojvodina has been faced with a decrease in the number of horses. At the same time, interest for sports horses and recreation is increasing. Taking into account the geographical position of our country, available pasture area, food production, labor force, and other suitable factors, we can conclude that much more has to be done to improve this livestock branch. The number of horses within controlled population from 2010 to 2016 recorded a positive trend, which is the result, first of all, implementation of the breeding programs. In 2017 there is a decrease of number of horse compared to 2016 by $2 \%$. If we compare the number of horses in the controlled population with the data of the Statistical Office of the Republic of Serbia from 2017, which tell us that there are about 6000 head of all categories in the AP Vojvodina, we obtain a percentage of horses that are within the controlled population and which is $28 \%$. 
From the moment when man domesticated the horse before the 50006000 years until today, horses are subject to many forms of selection which resulted in gradual genetic changes and the creation of many breeds. Within the controlled population it is mostly bred Lipizzaner, Thoroughbred and Nonius horses. The Lipizzaner breed is most represented in the controlled population. The number of horses in 2017 is 1.497. In the AP Vojvodina, two stud farms are distinguished: Karađorđevo and Kelebija, but the breeding is also largely represented by individual breeders. The next breed that is most represented is Nonius. Because strength of the skeleton, strong muscles, good walking and calm temperament Nonius are used primarily for agricultural works, while today it is mainly used for riding and for harness. This change in the role resulted in a drastic decrease in the Nonius population, so under the control of productivity in the Stud Book there are only 68 horses. In order to prevent further reduction in the number and loss of genes that may be of major importance in the future, the Ministry of Agriculture has included Nonius in the program for the conservation and sustainable use of genetic resources of domestic animals. Except in Serbia, Nonius is breeding in Hungary, Slovakia and Romania (Mihok et al., 2004; Maftei et al., 2011; Bene et al., 2014). The gallop sport in Vojvodina does not have such a long tradition, but quickly raises the reputation of horse breeding in one country. The specific rules of breeding Thoroughbred horses date from the $18^{\text {th }}$ century. The selection criterion has remained unchanged to date, and this is the result of the races. Controlled population of Thoroughbred horse is mostly represented on the stud farms Pik Bečej and Karađorđevo.

\section{Poultry production}

Breeding program in poultry is applied to the control the population of parents flock of meat type hybrids and parents flock hybrids for eggs production. The following meat type hybrids are represented: Ross 308, Cobb 500, Hubbard. Under control there is a flock of light hybrids - Tetra SL. In the area covered with our main breeding program in poultry is parents flock turkey - hybrid But Big 5 . The main breeding program in poultry is also planned to monitoring the production results chickens breeds of the following races: Amrock, Silver Italian Chickens, Sasex, New Hampshire, Brahma, Wyandotte, Australorp and Marans.

Continual control of the production of imported flocks is necessary with aim to exclude from the production those hybrids that give worse production results comparing with others in the region, and give to producers recommendation which hybrids to use. Production results are according with the technological norms of breeding hybrids, and the 
production results of individual hybrids indicate their end of usage on the territory of AP Vojvodina.

Table 5. Eggs production results parents flock of poultry in the period from 2010 to 2017 years

\begin{tabular}{|c|c|c|c|c|c|c|c|c|c|}
\hline $\begin{array}{l}\text { Para- } \\
\text { meters }\end{array}$ & $\begin{array}{c}\text { Ross } \\
308\end{array}$ & $\begin{array}{c}\text { Cobb } \\
500\end{array}$ & $\begin{array}{c}\text { Hubbard } \\
\text { F15 }\end{array}$ & $\begin{array}{c}\text { Hubbard } \\
\text { Red bro }\end{array}$ & $\begin{array}{c}\text { Hubbard } \\
\text { Classic }\end{array}$ & $\begin{array}{c}\text { Tetra } \\
\text { SL }\end{array}$ & $\begin{array}{c}\text { Isa } \\
\text { Brown }\end{array}$ & $\begin{array}{c}\text { But } \\
\text { Big } 5\end{array}$ & Year \\
\hline \multirow{8}{*}{ 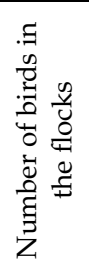 } & 213,663 & 53,334 & 8,163 & 0 & 97.218 & 14,267 & 0 & $2,335^{*}$ & 2010 \\
\hline & 137,938 & 82,726 & 8,719 & 0 & 43.351 & 0 & 0 & $2,322^{*}$ & 2011 \\
\hline & 217,006 & 103,195 & 0 & 0 & 0 & 13,315 & 11,941 & $2,388^{*}$ & 2012 \\
\hline & 143,933 & 23,001 & 63,402 & 0 & 0 & 15,369 & 0 & 2,273 & 2013 \\
\hline & 104,623 & 24,493 & 8,088 & 0 & 0 & 0 & 0 & 2,414 & 2014 \\
\hline & 137,804 & 90,913 & 8,047 & 2,889 & 0 & 15,391 & 0 & 2,340 & 2015 \\
\hline & 110,176 & 50,630 & 0 & 2,899 & 0 & 15,817 & 0 & 2,207 & 2016 \\
\hline & 150,179 & 52,065 & 0 & 0 & 0 & 15,471 & 0 & 2,207 & 2017 \\
\hline \multirow{8}{*}{ 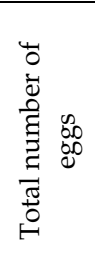 } & 138 & 136 & 159 & 0 & 135 & 240 & 0 & 96 & 2010 \\
\hline & 146 & 128 & 71 & 0 & 117 & 0 & 0 & 120 & 2011 \\
\hline & 161 & 142 & 0 & 0 & 0 & 232 & 173 & 98 & 2012 \\
\hline & 158 & 153 & 145 & 0 & 0 & 188 & 0 & 103 & 2013 \\
\hline & 163 & 179 & 130 & 0 & 0 & 0 & 0 & 100 & 2014 \\
\hline & 158 & 168 & 188 & 168 & 0 & 215 & 0 & 96 & 2015 \\
\hline & 173 & 140 & 0 & 131 & 0 & 255 & 0 & 78 & 2016 \\
\hline & 182 & 146 & 0 & 0 & 0 & 266 & 0 & 92 & 2017 \\
\hline
\end{tabular}

Note: * But Big 6

\section{Conclusion}

The milk yield in a recorded population of Holstein Friesian and Simmental cows shows evident phenotypic increasing trend as opposed to a population that is not controlled. It actually indicates the great importance of implementation of breeding programs on the development of dairy cattle production in Vojvodina. There are significant resources for the development of beef cattle production in Vojvodina. However, despite that, as well as preferential quotas for export of beef meat, and the opening of new markets, although demanding, but which have high payment power and where is a demand for beef, this branch of cattle production was not sufficiently developed.

The results of the selection measures in Vojvodina show that pig production has an upward trend and that we have more and more small and medium (family) farms.

Interest for sheep and goat production is increasing. This is primarily because of the high demand for products made from sheep meat and goat milk and meat, due to state subsidies and because of the geographical position and terrain of AP Vojvodina, which allow the breeding of highly productive goats. However, although sheep and goat production is rising, in general sheep and goat numbers remain very 
small. In future years, the main herd is expected to grow slightly more quickly as the number of young farmers opting for intensive sheep and goat breeding is increasing.

In the future, the horse breeding could be orientated in three directions: racing horses (trotter and Thoroughbred); sport horses and horses for recreational purpose; horses for tourism which would enable the preservation of locally adapted breed. Breeding of warmblood horse for sport could become the most important branch of horse breeding.

According with production results of parental flocks, covered with Main Breeding Program in the past period, we noticed increasing of the production of controlled flocks, and in same time reducing the number of breeding stock breeders.

\section{References}

Aleksić, S.-Pantelić, V.-Radović, Č. (2009): Livestock production - present situation and future development directions in Republic of Serbia. Biotechnology in Animal Husbandry. 25. 5-6: 267-276.

Bene, S.-Benedek, Z.-Nagy, S.-Szabo, F.-Polgar, J. P. (2014): Some effects on gestation length of traditional horse breeds in Hungary. Journal of Central European Agriculture. 15. 1: 1-10.

Bogdanović, V.-Đedović, R.-Perišić, P.-Petrović, M. M. (2005): Odgajivački ciljevi i programi u govedarstvu Srbije. Biotechnology in Animal Husbandry. 21. 5-6: 15-21.

Bucek, P.-Zottl, K.-Onken, F.-Klopčič, M.-Radzio, D.-Mészáros, G.-Barac, Z.-Ryba, Š.-Dianová, M.-Kučera, J. (2014): Practical aspects in milk recording in Central and Eastern Europe and its effects on the guidelines. ICAR Conference. Berlin.

Kmetijski Institut Slovenije (2018): Results of Dairy and Beef Recording Slovenia 2017. Ljubljana.

Maftei, M.-Popa, R.-Popa, D.-Mărginean, G.-Vidu, L.-Vlad, I.-Gîrlea, M.-Lăpuşte, T. (2011): Partial results regarding the genetic analysis of Nonius horse from Izvinstudfarm: reproductive isolation and age structure. Animal Science and Biotechnologies. 44. 1: 278-281.

Main breeding organization (Department of animal science, Faculty of agriculture) (2011): Annual report 2010 about implementation of breeding measures in livestock Vojvodina. Novi Sad.

Main breeding organization (Department of animal science, Faculty of agriculture) (2018): Annual report 2017 about implementation of breeding measures in livestock Vojvodina. Novi Sad.

Mekić, C.-Perišić, P.-Vuić, R. P.-Novaković, Z. (2017): Variability of Sjenica pramenka reproductive parameters depending of season, mating urge and gonadotropic hormones application. The International symposium on animal science (ISAS). Book of abstracts. 05-10 June 2017. Herceg Novi. Montenegro. 
Mekić, C.-Trifunović, G.-Novaković, Z.-Vujić, R.-Romić, D. (2011): Polno ponašanje ovaca $u$ zavisnosti od primene biotehnoloških metoda. XVI međunarodno naučno-stručno savjetovanje agronoma Republike Srpske. Trebinje. Zbornik sažetaka str. 85.

Mihok, S.-Ban, B.-Jozsa, Cs.-Bodo, I. (2004): Estimation of genetic distance between traditional horse breed in Hungary. Conservation genetics of engendered horse breed. EAAP Publications - Bled. Slovenia. 111-121.

Novković, N.-Mutavdžić, B.-Ivanišević, D.-Tešić Miličić, M. (2011): Stanje i perspektive razvoja stočarstva u Vojvodini. Prethodno saopštenje. Škola biznisa. 1: 89-100.

Pihler, I.-Simin, V.-Maksimović, N.-Stanišić, N.-Žujović, M.-Ćirić, J. (2014): Caracteristics of reproduction and milk yield of Alpine and Saanen goat breeds in Vojvodina. European Regional Conference on Goats „ERCG 2014“. 7-13 April 2014. Debrecen-Hungary/Oradea-Romania.

Popović, R. (2014): Stočarstvo u Republici Srbiji, Popis poljoprivrede 2012. godine. Republički zavod za statistiku.

Radović, I.-Mirkov, M.-Konjević, S.-Zarković, I.-Vasiljević, V. (2015): Implementation Of The "Breeding Program" In Pig Production In Vojvodina Province (Serbia). Sixth International Scientific Agricultural symposium "Agrosym 2015".

Stanišić, Z.-Šupica, M. (1987): Sportski konji. Uzgoj i trening. Poljoprivredna literatura. Nolit.

Statistical Office of the Republic of Serbia (2017): Annual report of the Republic of Serbia by year.

Stokovic, I.-Ekert Kabalin, A.-Karolyi, D.-Sakic, V.-Miscevic, B.-Daud, J.-Staric, J.Bunevski, G. (2007). Cattle production trends in the region of ex Yugoslavia. http://www.eaap.org/docs/newsletters/2007-07/Cattlenetwork

Trivunović, S.-Janković, D.-Ivanović, D.-Radinović, M.-Šoronja, Ž. (2015): Effects of the implementation of the breeding programs to develop dairy cattle breeding in Vojvodina. 2nd International Symposium for agriculture and food ISAF 2015. Book of Abstracts. 7-9 October 2015. Ohrid. Republic of Macedonia. 21.

Trivunović, S.-Radović, I.-Pihler, I.-Janković, D. (2014): Sprovođenje odgajivačkih programa u stočarstvu AP Vojvodine. $7^{\text {th }}$ International scientific/professional conference: Agriculture in nature and environment protection. Vukovar. Republic of Croatia. 37-47.

Yoo, C. Y.-Lee, H. J. (2011): Analysis of disqualifying factors for boars tested on performance at the second, Korea swine testing stationfrom 2007 to 2009. Korean Journal of Veterinary Public Health. Vol. 35. 